\title{
Effect of Horse Riding Simulator Exercise on Thickness of Transverse Abdominis in Healthy Adults
}

\author{
JaeHyo Park', YoungMi Kim² \\ 'Department of Physical Therapy, College of Biomedical Science, Daegu Haany University; ${ }^{2}$ Department of Physical Therapy, Andong Science \\ College, Andong, Korea
}

Purpose: This study examined the effects of horse riding simulator exercise on the thickness changes in the transverse abdominis in normal adults.

Methods: Forty-five healthy adults were recruited and randomized to a horseback riding simulation exercise group $(n=15)$, a sling exercise group $(n=15)$, and a trunk stabilization exercise group $(n=15)$. A horseback riding simulator offers the indoor experience of horseback riding and mimics the rhythmic movement of horseback riding, thereby provided a virtual environment, such as riding a real horse on the front screen. The velocity of the horse riding simulator exercise was regulated within the subject's ability to control the exercise on the horse riding simulator. A sling exercise group performed sling exercise under the inspection of the experimenter. In the trunk stabilization exercise group, the subjects were instructed to perform the exercise accurately and pause the session when pain occurred during the intervention. The subjects in each group carried out the interventions three times per week for six weeks. The thickness of the transverse abdominis was measured using a pressure biofeedback unit and the ultrasound.

Results: Significant differences in the thickness of transverse abdominis within the groups were observed between before and after the interventions. On the other hand, there were no differences in the parameters among the groups.

Conclusion: Horse riding simulator exercise can be an alternative to trunk stabilization exercise by increasing the thickness of the transverse abdominis in healthy adults.

Keywords: Horse riding simulator Exercise, Ultrasound, Transverse abdominis

\section{서 론}

체간 안정화는 물리치료와 운동 분야에서 중요하게 여겨지고 있으 며, ${ }^{\prime}$ 이와 관련된 연구가 다양하게 이루어지고 있다. 신체의 안정화를 담당하며 체간을 잡아주는 근육에는 기능과 크기, 위치에 따라 대근 육(global muscle)과 소근육(local muscle)으로 구분할 수 있다. 대근육 은 표층에 위치하여 큰 힘을 내는 근육들이고, 가슴우리와 골반을 연결해주며, 체간에 적용되는 외부 부하에 대한 균형을 제공해 준다. 소근육은 심부에 위치하며 척추의 역학적인 안정성을 확보하게 해준 다. 이러한 소근육은 배가로근(transverse abdominis), 배속빗근(internal oblique) 등과 같은 복벽의 심부 근육을 포함하고 척추 사이 분절 의 안정성을 담당한다. ${ }^{2}$ Hodges와 Richardson ${ }^{3}$ 의 연구에 의하면 사지 의 움직임이 일어나기 전에 복부 근육 중 가장 먼저 활성화되는 근육
은 배가로근이며 배속빗근, 가로막, 골반아래근과 함께 복부 내압을 생성하고 조절하며 요추부의 강도를 증가시켜 체간의 안정성을 향상 시켜 준다고 하였다.

체간 안정화를 위한 중재는 신경근 조절 및 근력과 근지구력을 증 진시켜 척추와 체간의 동적 안정성을 유지할 수 있도록 하며, ${ }^{4}$ 특히, 물리치료와 스포츠 영역에서 근력의 최대화, 지구력의 향상, 그리고 균형 능력의 향상 및 부상 예방 목적을 위해 실시된다. ${ }^{5}$ 체간 안정화 중재에 관한 연구는 자세와 도구, 환경 등에 따라 다양하게 실시되고 있다. 최근 분절 안정화 모델에 따른 체간 안정화 운동으로 요통환자 의 체간 안정성과 족저압에 효과가 있었다고 하였고, ${ }^{6}$ 도구를 이용한 운동으로는 슬링 운동이 체간 안정화에 기여 할 수 있으며 치료적 효 과가 있다고 하였으며,8. 치료용 볼을 이용한 복부 강화 운동은 운동 을 하는 동안 불안정한 면을 제공하여 체간근에 더 큰 부하를 제공
Received Mar 19, 2019 Revised Apr 8, 2019

Accepted Apr 30, 2019

Corresponding author YoungMi Kim

E-mail h1015m@naver.com
Copylight (C)2019 The Korean Society of Physical Therapy

This is an Open Access article distribute under the terms of the Creative Commons Attribution Non-commercial License (Http:// creativecommons.org/license/by-nc/4.O.) which permits unrestricted non-commercial use, distribution, and reproduction in any medium, provided the original work is properly cited. 
함으로써 더 많은 안정성의 향상을 기대할 수 있다고 하였다. ${ }^{9}$

체간 안정성 향상과 균형능력 향상을 위한 여러 다양한 중재법 중 최근 말과 함께 하는 치료승마(hippotherapy)의 효과가 주목 받고 있 다. 말을 타게 되면 리드미컬하고 반복적인 말의 움직임이 몸 전체의 고유수용성 감각수용기에 전달이 되어 몸의 중심을 위아래, 좌.우, 회전을 시키게 되는데 이것은 사람이 걸을 때 체간과 골반의 움직임 패턴과 비슷하다고 한다. ${ }^{10}$ 승마를 통해 얻을 수 있는 이런 긍정적인 효과들은 정상인 뿐 아니라 뇌성마비, 다발성 경화증, 뇌졸중, 척수 손상 등 중추신경계 손상으로 인해 장애를 가진 환자들의 정상적인 기능을 회복시키는데도 영향을 끼치게 된다고 보고하였다.11,12

Stevens 등 ${ }^{13}$ 의 연구에 의하면 배가로근과 배속빗근 등과 같은 허리 뼈의 심부근이 요부에 안정성을 제공하는데 큰 역할을 한다고 하였 다. Standaert 등 ${ }^{14}$ 은 기능적 활동시 복부 내압이 증가하게 되는데 체 간 심부근 중에 특히 배가로근이 체간의 안정화 근육으로 활성화 된 다고 하였다. 또한 Richardson 등 ${ }^{15}$ 의 연구에 의하면 체간을 안정화시 키는 근육은 배가로근이며 요통을 가지고 있는 사람의 경우 다른 근 육의 동원이 먼저 나타나게 된다고 하였다. 이와 같이 체간 심부근들 은 원위부의 가동성을 촉진시켜 주며, 기능적 운동 사슬의 중심 역할 을 하여 체간의 안정성을 향상시켜 준다. ${ }^{16}$ 이에 본 연구에서는 정상 성인을 대상으로 6주 동안의 승마 기구 운동과 임상에서 체간 안정 화 운동으로 널리 쓰이며 많은 연구가 진행된 슬링운동과 보존적 체 간 안정화 운동을 실시하여 배가로근 두께에 어떠한 영향을 미치는 지를 알아보고자 하였다.

\section{연구 방법}

\section{1. 연구대상}

본 연구는 2014년 7월부터 9월까지 건강한 20대 성인 남녀 45명을 대 상으로 승마기구 운동군 15 명, 슬링 운동군 15 명, 체간 안정화 운동 군 15 명으로 무작위로 배치하였다. 연구에 참여할 대상자의 선정 기 준은 첫째, 연구에 영향을 미칠 만한 근골격계 및 기타 질환의 병력 과 기능장애가 없는 자, 둘째, 대상자 선정 당시 1 주일에 2 회 이상 규 칙적인 운동을 하고 있지 않은 자로 하였다.
연구 대상자의 일반적인 특성은 각 그룹별 연령, 신장, 체중에서 통 계학적으로 유의한 차이는 없었고, 연구 대상자의 일반적 특성은 다 음과 같다(Table 1). 연구대상자들에게 실험을 실시하기 전 연구의 목 적과 절차에 대하여 설명을 하였고, 참여한 대상자들은 모두 이에 동 의를 하였으며, 대구대학교 생명윤리위원회의 승인을 받았다(1040621201501-HR-005-08).

\section{2. 실험방법}

1) 측정도구

(1) 초음파(ultra-sonograph)

본 연구의 중재 전.후 배가로의 두께 변화를 측정하기 위해 초음파 영상 진단 장비(Terason $\mathrm{t} 3000$ ultrasound system, apple, America)를 사 용하였다. 배가로근의 두께 측정은 복부 드로잉-인 방법(abdominal drawing-in maneuver, $\mathrm{ADIM}$ )을 적용할 동안 초음파 촬영을 실시하였 다. ADIM은 복벽을 안쪽으로 당김으로 내복압을 증가시키기 위해 배가로근과 배속빗근만을 수축하는 방법으로 체간의 안정화 훈련 을 효과적으로 수행하게 하며, 근육의 동시수축을 유도하여 과도한 허리의 전만이나 골반의 전방경사를 방지해 주는 방법이다. ${ }^{17}$ 연구 대 상자는 바로 누운 자세에서 무릎 밑에 삼각 받침대를 이용하여 무릎 이 30도 정도 굴곡된 자세로 실시하였다. ${ }^{18} \mathrm{PBU}$ (pressure biofeedback unit, Stabilizer, USA)의 에어백은 대상자의 허리뼈(lumbar spine) 부위 에 위치하게 하고, 대상자는 PBU의 압력계를 보면서 복부 심부근의 활성화를 위해 $\mathrm{ADIM}$ 을 하게 하였다. 이때 대상자가 불필요한 동작 을 하지 않도록 검사자는 주시하며 대상자가 ADIM을 통해 심부근 을 정확히 수축하도록 중재한다. ${ }^{19}$ 측정은 $\mathrm{PBU}$ 의 압력을 $20 \mathrm{mmHg}$ 로 맞춘 상태에서 힘을 빼고 편안하게 누운 자세를 시작 자세로 하고 한 단계에 $5 \mathrm{mmHg}$ 씩 압력이 올라가도록 $20 \mathrm{mmHg}, 25 \mathrm{mmHg}, 30 \mathrm{mmHg}$ 까지 총 3 단계로 $\mathrm{ADIM}$ 을 실시하여 복부 심부근의 수축이 일어나도 록 하였다. 각 단계마다 10 초를 유지하게 하여 측정하고, 각 단계마다 30 초간 휴식을 취하게 하였다. ${ }^{20}$ 배가로근의 두께 측정은 근막으로부 터 분리되는 경계부분에서 근육의 중심부 방향으로 $1 \mathrm{~cm}$ 떨어진 지 점의 동일한 위치에서 측정하였다. ${ }^{21}$ 측정한 위치는 엉덩뼈 능선과 갈 비뼈 하각 사이에서 중앙 액와 선상에 있는 앞가쪽 지점을 측정하였

Table 1. General characteristics of subjects.

\begin{tabular}{|c|c|c|c|c|c|}
\hline & HRS group & SE group & TSE group & $\mathrm{F}$ & $p$ \\
\hline $\mathrm{n}$ & 15 & 15 & 15 & & \\
\hline $\operatorname{Sex}(M / F)$ & $7 / 8$ & $7 / 8$ & $7 / 8$ & & \\
\hline Age (years) & $21.53 \pm 2.35$ & $21.40 \pm 1.50$ & $22.40 \pm 1.88$ & 1.169 & 0.321 \\
\hline Height (cm) & $165.73 \pm 6.23$ & $168.73 \pm 9.31$ & $168.06 \pm 8.59$ & 0.559 & 0.576 \\
\hline Weight (kg) & $58.13 \pm 7.42$ & $61.13 \pm 9.42$ & $57.26 \pm 9.74$ & 0.924 & 0.405 \\
\hline
\end{tabular}

Mean \pm SD: mean \pm standard deviation, ${ }^{*} p<0.05$, HRS group: horse riding simulator group, SE group: sling exercise group, TSE group: trunk stabilizing exercise group. 
다. ${ }^{22,23}$ 각 단계에서 두 번 반복 실시하여 이미지를 저장하고, 가장 좋 은 영상을 선택하였다. 초음파 기기안의 두께 측정 메뉴를 이용하여 근 두께를 기록하였으며 초음파 촬영 및 근 두께의 모든 측정은 검사 자 1 명이 실시하였다.

(2) 압력 생체 되먹임 기구(pressure biofeedback unit) 초음파 진단시 배가로근의 수축력을 일정하게 측정하기 위하여 압력 생체 되먹임 기구(PBU, pressure biofeedback unit, Stabilizer, USA)를 사 용하였다. $\mathrm{PBU}$ 는 운동의 질적인 면과 정확도에 대한 피드백을 제공 하는 간단한 기구로 목, 허리 그리고 골반 부위의 안정성을 높이는 운 동에 주로 이용되고 있다. Cairns 등은 PBU로 압력을 측정함으로써 간접적으로 복근의 활성화 정도를 알아볼 수 있다고 하였다. ${ }^{24}$ 본 연 구에서 배가로근의 수축으로 인해 발생되는 근력은 $\mathrm{PBU}$ 에 가해지는 압력으로 표현된다. 측정 단위는 $\mathrm{mmHg}$ 를 사용하였다

\section{2) 중재방법}

(1) 승마기구 운동(horse riding simulator)

본 연구에서 사용한 승마운동기구는 실내 승마기(H-702, Hongjin le-

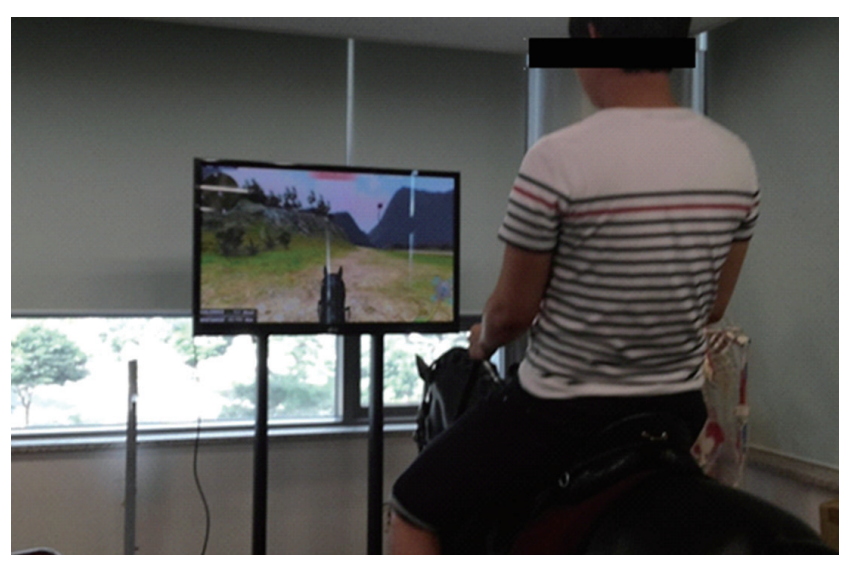

Figure 1. Horse riding simulator, Korea

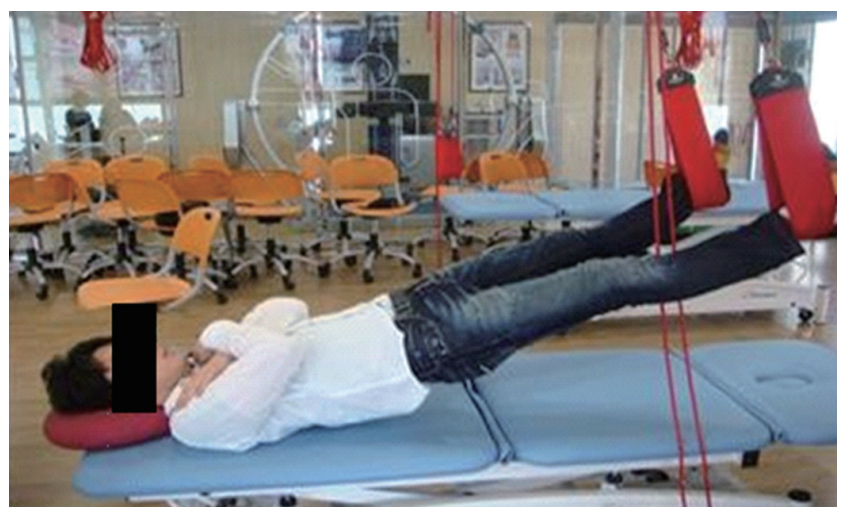

Figure 2. pelvic elevation exercise in supine position ports, Korea)로 승마기구 운동을 하는 동안 정면 스크린에 실제 말을 타는 것과 같은 가상환경을 구동함으로써 기승자가 스크린에 나타 나는 시각 정보를 통해 실제 말을 타는 것과 같은 효과를 가져 올 수 있다. 승마기구 운동은 6주간 주 3 회 회당 20 분씩 실시하였다. 승마운 동기구를 사용하는 동안 실험자의 관리 하에 대상자는 올바른 자세 를 유지하며 승마기구 운동을 시행하였고 통증이 발생하면 중단하 였다. 승마기구 운동의 속도는 대상자의 신체 능력에 따라 평보에서 속보 사이를 조절하며 시행하였다. 평보는 말의 걷는 방법 중에 가장 느린 것으로, 걷는 속도는 1 분에 약 $110 \mathrm{~m}$ 를 표준으로 한다. 속보의 속 도는 1 분에 약 $220 \mathrm{~m}$ 를 표준으로 한다(Figure 1).

\section{(2) 슬링 운동(sling exercise)}

슬링 운동은 실험자의 관리 하에 대상자가 정확한 운동이 일어나도 록 하였으며 6주간주 3 회 20분씩 시행하였다.

(1) 슬링 운동의 첫 번째는 바로 누운자세에서 머리에 동그란 에어 쿠션을 받치고 양손은 교차해서 어깨에 댄 자세를 취한다. 슬링 의 위치는 엉덩관절과 무릎관절이 각각 90 도가 되도록 위치한 상태에서 발뒤꿈치에 걸고 난 뒤 다리를 쭉 편 다음 골반을 들 어 올린 후 10 초간 유지하는 것을 4 회 $1 \mathrm{set}, 10 \mathrm{set}$ 실시한다. set간 에는 10초 휴식을 취한다(Figure 2).

(2) 슬링 운동의 두 번째는 엎드린 자세에서 무릎뼈 아래에 슬링을 위치시키고 슬링의 높이는 어깨와 일직선이 되도록 유지하고 팔 꿈치와 아래팔을 침대 바닥에 지지한 자세로 허리를 들어 올린 다. 허리를 들어 올린 상태로 10 초간 유지하는 것을 4 회 $1 \mathrm{set}, 10$ set실시한다. set간에는 10 초 휴식을 취한다. 이 운동을 할 때는 배 밑에다가 에어쿠션을 두 개정도 받치고 실시한다(Figure 3).

\section{(3) 체간 안정화 운동(trunk stability exercise)}

체간 안정화 운동은 6 주간 주 3 회 실시하였다. 체간 안정화 운동 시 실험자의 관리하에 정확한 동작을 취할 수 있도록 하였으며 통증이

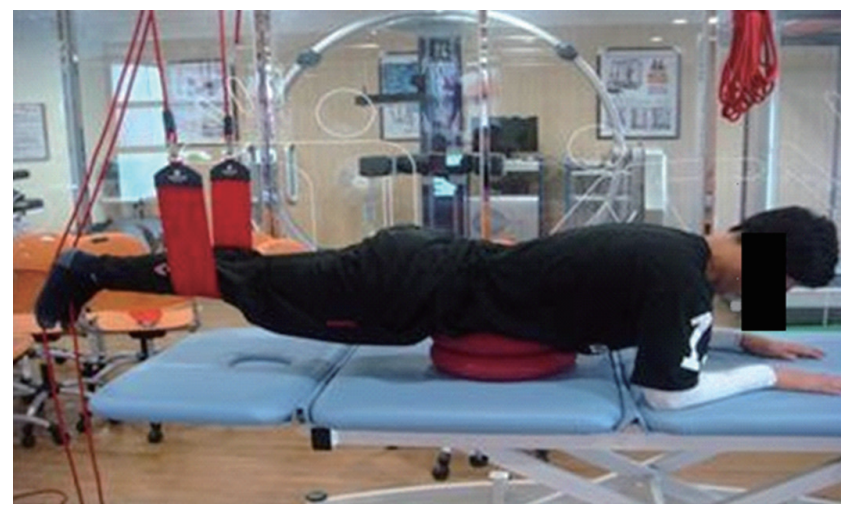

Figure 3. prone on elbow position in prone position 
발생하면 운동을 중단하였다.

(1) abdominal drawing-in maneuver (ADIM)

(a) 대상자는 바로 누운 자세에서 양쪽 발이 바닥에 위치하도록 한다.

(b) 골반을 후방경사 시키면서 위쪽 아래로 대상자 스스로 복부 압 력을 가하면서 5 초, 10 초, 15 초, 20 초로 점진적으로 시간을 늘리 면서 유지한다.

(2) 몸통의 고리모양(crul-ups)만들기 운동

(a) 대상자는 바로 누운 자세에서 양쪽 발이 바닥에 위치하도록 한다.

(b) 턱을 앞으로 당기고 어깨뼈가 전인이 되도록 하며 양쪽 상지를 외회전 시킨다.

(c) 양쪽 상지를 무릎 방향으로 향하도록 하며, 동시에 머리와 상부 몸통이 바닥에서 들리도록 한 후 5 초, 10 초, 15 초, 20 초로 점진적 으로 시간을 늘리면서 유지한 후 몸통과 머리를 천천히 내린다.

(3) 교각 운동(bridging exercise)

(a) 무릎관절 90도 굽힘 상태에서 양 팔은 약 30도 벌림하고, 손바 닥은 지면으로 향하게 한다.

(b) 무릎과 양 발을 어깨 넓이로 벌리고 발바닥은 지면에 11자로 놓 게 한다. 머리와 목은 일자로 유지하였으며 시선은 천장을 바라 보게 한다.

(c) 대상자는 측정자의 지시에 따라 골반을 고관절 굴곡 0 도가 될 때까지 들어 올리고 5초, 10 초, 15 초, 20 초로 점진적으로 시간을 늘리면서 유지한 후 골반을 천천히 내린다.

(4) 골반 저항과 함께 하체 회전(rotation with resistance from pelvis)

(a) 대상자는 바닥 위에 바로 누워 무릎을 구부리고 발을 바닥에서 $10 \mathrm{~cm}$ 정도 올린다. (b) 대상자의 어깨가 가능한 바닥에서 떨어지지 않고 몸통을 유지 한 채 천천히 좌우로 하지를 회전 시키게 한다.

(c) 하지의 회전은 대상자의 상태에 따라 작은 범위에서 큰 범위로 움직인다.

\section{3) 자료분석}

본 연구에서의 통계 처리는 연구의 목적을 위해 수집된 자료를 IBM SPSS Statistics 20.0 KO (IBM, IL, USA) 통계프로그램을 이용하였다. 대 상자의 일반적 특성은 기술통계로 분석하였으며, 그룹 내 중재 전. 후 차이 검증을 위하여 대응표본 $\mathrm{t}$-검정을 실시하였고 세 그룹 간 중재 방법에 따른 종속변수의 차이를 비교하기 위하여 일원배치분산분석 (one-way ANOVA)을 실시하였으며 훈련 후 세 그룹 간의 중재 형태에 따른 차이를 알아보기 위해 LSD의 사후검정을 실시하였다. 통계학적 유의 수준은 0.05 로 설정하였다.

\section{결 과}

\section{1. $20 \mathrm{mmHg}$ 압력에서 배가로근 두께 비교}

배가로근의 두께는 중재 전 승마기구운동 그룹은 $2.95 \pm 0.05 \mathrm{~mm}$, 슬 링 운동 그룹은 $3.36 \pm 0.11 \mathrm{~mm}$, 체간 안정화 운동 그룹은 $2.90 \pm 0.07$ $\mathrm{mm}$ 이었고, 중재 6주 후 승마기구운동 그룹은 $3.05 \pm 0.04 \mathrm{~mm}$, 슬링 운 동 그룹은 $3.41 \pm 0.11 \mathrm{~mm}$, 체간 안정화 운동 그룹은 $2.95 \pm 0.07 \mathrm{~mm}$ 로 나타났고, 모든 그룹에서 중재 전후 유의한 변화를 보였다 $(\mathrm{p}<0.05)$. 그 러나 중재 전후 차이값으로 분석한 배가로근의 두께는 그룹간 유의한 차이가 없었다 $(\mathrm{p}>0.05)($ Table 2$)$.

Table 2. The results of TrA thickness on each groups at pre-post intervention.

(unit:mm)

\begin{tabular}{|c|c|c|c|c|c|}
\hline & Group & pre-test & post-test & $\mathrm{t}$ & $\mathrm{p}$ \\
\hline \multirow[t]{5}{*}{$20 \mathrm{mmHg}$} & HRS & $2.95 \pm 0.05$ & $3.05 \pm 0.04$ & -3.87 & $0.002^{*}$ \\
\hline & SE & $3.36 \pm 0.11$ & $3.41 \pm 0.11$ & -4.00 & $0.001^{*}$ \\
\hline & TSE & $2.90 \pm 0.07$ & $2.95 \pm 0.07$ & -2.82 & $0.014^{*}$ \\
\hline & $\mathrm{F}$ & 1.487 & 1.417 & & \\
\hline & $P$ & 0.238 & 0.254 & & \\
\hline \multirow[t]{5}{*}{$25 \mathrm{mmHg}$} & HRS & $4.19 \pm 0.08$ & $4.89 \pm 0.08$ & -5.26 & $0.000^{*}$ \\
\hline & SE & $4.52 \pm 0.11$ & $5.08 \pm 0.11$ & -5.34 & $0.000^{*}$ \\
\hline & TSE & $4.07 \pm 0.07$ & $4.46 \pm 0.09$ & -4.01 & $0.001^{*}$ \\
\hline & $\mathrm{F}$ & 1.115 & 1.821 & & \\
\hline & $\mathrm{P}$ & 0.338 & 0.174 & & \\
\hline \multirow[t]{5}{*}{$30 \mathrm{mmHg}$} & HRS & $4.33 \pm 0.08$ & $4.89 \pm 0.08$ & -4.89 & $0.000^{*}$ \\
\hline & SE & $4.69 \pm 0.11$ & $5.13 \pm 0.11$ & -3.99 & $0.001^{*}$ \\
\hline & TSE & $4.19 \pm 0.07$ & $4.51 \pm 0.09$ & -3.23 & $0.006^{*}$ \\
\hline & $\mathrm{F}$ & 1.387 & 1.645 & & \\
\hline & $P$ & 0.261 & 0.205 & & \\
\hline
\end{tabular}

Mean \pm SD: mean \pm standard deviation, $* p<0.05$, TrA: transverse abdominis, HRS group: horse riding simulator group, SE group : sling exercise group, TSE group : trunk stabilizing exercise group. 


\section{2. $25 \mathrm{mmHg}$ 압력에서 배가로근 두께 비교}

배가로근의 두께는 중재 전 승마기구운동 그룹은 $4.19 \pm 0.081 \mathrm{~mm}$, 슬 링운동 그룹은 $4.52 \pm 0.111 \mathrm{~mm}$, 체간 안정화 운동 그룹은 $4.07 \pm 0.071$ $\mathrm{mm}$ 이었고, 중재 6주 후 승마기구운동 그룹은 $4.89 \pm 0.081 \mathrm{~mm}$, 슬링 운동 그룹은 $5.08 \pm 0.111 \mathrm{~mm}$, 체간 안정화 운동 그룹은 $4.46 \pm 0.091$ $\mathrm{mm}$ 로 나타났고, 모든 그룹에서 중재 전후 유의한 변화를 보였다 $(\mathrm{p}<0.05)$. 그러나 중재 전후 차이값으로 분석한 배가로근의 두께는 그 룹간 유의한차이가 없었다( $\mathrm{p}>0.05)$ (Table 2).

\section{3. $30 \mathrm{mmHg}$ 압력에서 배가로근 두께 비교}

배가로근의 두께는 중재 전 승마기구운동 그룹은 $4.33 \pm 0.081 \mathrm{~mm}$, 슬 링 운동 그룹은 $4.69 \pm 0.11 \mathrm{~mm}$, 체간 안정화 운동 그룹은 $4.19 \pm 0.071$ $\mathrm{mm}$ 이었고, 중재 6주 후 승마기구운동 그룹은 $4.89 \pm 0.081 \mathrm{~mm}$, 슬링 운동 그룹은 $5.13 \pm 0.111 \mathrm{~mm}$, 체간 안정화 운동 그룹은 $4.51 \pm 0.091 \mathrm{~mm}$ 로 나타났고, 모든 그룹에서 중재 전후 유의한 변화를 보였다 $(\mathrm{p}<0.05)$. 그러나 중재 전후 차이값으로 분석한 배가로근의 두께는 그룹간 유의 한차이가 없었다 $(\mathrm{p}>0.05)($ Table 2$)$.

\section{고 찰}

본 연구는 정상 성인을 대상으로 6 주 동안의 승마 기구 운동과 슬링 운동 및 체간 안정화 운동을 실시하여 배가로근 두께에 어떠한 영향 을 미치는지를 알아보고자 하였다.

본 연구에서 중재 전후 배가로근의 두께는 승마기구 운동 그룹, 슬 링 운동 그룹, 체간 안정화 운동 그룹 모두 통계적으로 유의성이 있었 다. 먼저 $20 \mathrm{mmHg}$ 압력의 $\mathrm{ADIM}$ 을 하지 않은 상태에서의 배가로근 의 두께는 승마기구 운동 그룹, 슬링 운동 그룹, 체간 안정화 운동 그 룹 모두에서 중재 전후 두께 변화에 유의한 차이를 보였다. 그러나 통 계적으로 유의 하게 나타났으나 ADIM을 하지 않은 $20 \mathrm{mmHg}$ 압력에 서의 두께 차이는 중재 전후 $1 \mathrm{~mm}$ 정도로 거의 차이가 나지 않았다. 이는 Critchley 등 25 의 연구에서 8 주간 필라테스 운동 후 누운 자세, 앉 은 자세 그리고 서 있는 자세에서 배가로근의 두께 변화가 없고 필라 테스 동작을 할 때에만 배가로근의 두께 변화가 나타난 것으로 보고 된 선행 연구의 결과처럼 본 연구에서도 안정시 배가로근의 두께 차 이는 통계적으로 유의성은 있었으나세 그룹 모두 중재 전후 $1 \mathrm{~mm}$ 정 도로 배가로근 두께 차이는 근소하였다. 이는 체간의 안정성을 담당 하고 있는 배가로근의 역할이 체간의 안정 시보다는 체간을 움직이 는 동작 시에 수축을 하면서 더 많은 영향을 주는 것으로 사료되어진 다. $\mathrm{ADIM}$ 을 시행하여 근수축을 일으킨 $25 \mathrm{mmHg}$ 압력에서는 승마 기구 운동 그룹, 슬링 운동 그룹, 체간 안정화 운동 그룹 모두에서 중 재 전후 배가로근 두께 변화에 유의한 차이를 보였다. 편마비 환자들
을 대상으로 초음파의 시각적 피드백을 이용하여 체간 안정화 운동 을 한 연구에서 체간 안정화 운동을 하루 30 분씩 5 주 동안 실시한 실 험군에서 배가로근의 두께는 유의하게 증가 하였고, ${ }^{26}$ 전춘배 ${ }^{27}$ 의 연 구에서 체간 안정화 운동은 배가로근 두께의 향상에 효과적이라고 볼 수 있다고 하였다. 이러한 선행 연구에서의 결과를 볼 때 본 연구 에서 승마기구 운동 그룹, 슬링 운동 그룹, 체간 안정화 운동 그룹 모 두에서 중재 전후 배가로근 두께 변화에 유의한 차이를 나타낸 결과 는 승마기구 운동 또한 체간 안정화 운동이 이루어지며 복부 심부근 특히 배가로근 두께 향상에 효과적이라는 것을 뒷받침해준다. 이는 실내 승마기구 운동을 이용하여 여대생을 대상으로 매주 3 회, 1 시간 씩의 12 주간의 승마기구운동을 실시한 후 넙다리와 허리 근력의 유 의한 증가 향상을 보고한 선행 연구와도 일치한다. ${ }^{28} \mathrm{ADIM}$ 을 시행하 여 근수축을 일으킨 $30 \mathrm{mmHg}$ 압력에서도 앞의 결과와 마찬가지로 승마기구 운동 그룹, 슬링 운동 그룹, 체간 안정화 운동 그룹 모두에 서 중재 전후 배가로근 두께 변화에 유의한 차이를 보였다. 배가로근, 배속빗근, 배바깥빗근 등의 근육들은 자세적 조절뿐만 아니라 체간 안정화에도 중요한 역할을 한다고 하였으며, 그 중 배가로근은 가장 큰 역할을 담당하며 체간 안정화에 중요한 요소라고 보고하였다. ${ }^{29}$ $\mathrm{Seo}$ 등 26 의 실시간 초음파 영상으로 확인한 연구 결과에서도 체간 안 정화 운동을 실시한 그룹에서 근수축 시 배가로근의 근육 두께 변화 율이 크게 나타났다. Vera-Garcia 등ㄱㄱㄱ Behm 드ㅇㅣㅣ은 안정된 지면보다 불안정한 지면에서 운동을 실시하는 것이 심부 근육의 활성화를 증 가 시킨다고 하였다. 이처럼 승마기구 운동을 하는 동안 기승자는 10 분에 500-1,000회의 신체적 움직임이 나타나며, 전후, 좌우, 상하의 3 차원적인 역동적인 운동이 기승자의 골반에도 동일한 움직임을 가 져 와서 복부 심부근에도 영향을 미치는 것으로 사료된다.

본 연구에서 승마기구 운동 그룹, 슬링 운동 그룹, 보존적 체간 안 정화 운동 그룹의 그룹간 비교에서는 유의하게 나타나지 않았지만 승마기구운동 그룹에서 중재 전후 비교에서 차이가 가장 많이 발생 하였다. 따라서, 선행 연구들과 같이 승마기구 운동은 흔들리는 불안 정한 말의 움직임을 통해 고유수용성 감각을 자극하고 체간 안정화 근육인 복부 심부근을 자극하여 신체의 안정성 증진에 도움이 되는 효율적인 운동방법으로 사료되며 본 연구의 결과로 승마기구 운동 은 배가로근의 두께 증가와 체간 안정성 개선에 효과적인 중재법의 대안이 될 수 있을 거라 생각된다.

본 연구는 그 결과를 해석하는 데 있어서 몇 가지 제한점을 가지고 있다. 본 연구에 참여한 대상자 수가 많지 않아서 본 연구의 결과를 모든 사람들에게 일반화시키는데 어려움이 있으며 중재의 적용기간 이 충분하지 못하였다. 또한 대상자들에 대한 통제가 제대로 이루어 지지 않았다. 따라서 앞으로 이러한 문제들을 개선한 연구가 시행되 어야 할 것이라고 생각된다. 체간 안정화 근육의 기능은 신체 정렬을 
유지하고 기능적인 활동 시에 자세 균형을 유지하고 효과적인 움직 임을 유도한다고 하지만 본 연구에서는 균형에 대한 부분은 확인하 지 못하였으므로 향후 승마기구운동이 균형에 미치는 영향에 대한 후속 연구가 더 필요할 것으로 보인다.

\section{REFERENCES}

1. Gamble P. An integrated approach to training core stability. Strength and Conditioning Journal. 2007;29(1):58-68

2. Carter JM, Beam WC, McMahan SG et al. The effects of stability ball training on spinal stability in sedentary individuals. J Strength Cond Res. 2006;20(2):429-35.

3. Hodges PW, Richardson CA. Contraction of the abdominal muscles associated with movement of the lower limb. Phys Ther. 1997;77(2):132 42 ;

4. Imai A, Kaneoka K, Okubo Y et al. Trunk muscle activity during lumbar stabilization exercises on both a stable and unstable surface. J Orthop Sports Phys Ther. 2010;40(6):369-75.

5. Gottschall JS, Mills J, Hastings B. Integration core exercises elicit greater muscle activation than isolation exercises. J Strength Cond Res. 2013; 27(3):590-6.

6. Lee W-J, Park S, Park J-W. Influence of trunk stabilization exercise upon the lumbar stabilization and foot pressure in patients with back pain. J Kor Phys Ther. 2014;26(1):21-6.

7. Kim SY, Kwon JH. Lumbar stabilization exercises using the sling system. J Kor Aca Ortho Man Phys Ther. 2001;7(2):23-39.

8. Kim BG, Se HK, Jung YW. The effect of sling exercise on lumbar stabilization and muscle strength. J Kor Phys Ther. 2004;16(4):129-47.

9. Garcia-Vaquero MP, Moreside JM, Brontons-Gil E et al. Trunk muscle activation during stabilization exercises with single and double leg support. J Electromyogr Kinesiol. 2012;22(3):398-406.

10. Sterba JA, Rogers BT, France AP et al. Horseback riding in children with cerebral palsy: Effect on gross motor function. Dev Med Child Neurol. 2002;44(5):301-8.

11. Beinotti F, Correia N, Christofoletti G et al. Use of hippotherapy in gait training for hemiparetic post-stroke. Arg Neuropsiquiatr. 2010;68(6): 908-13.

12. Bronson C, Brewerton K, Ong J et al. Does hippotherapy improve balance in persons with multiple sclerosis: A systematic review. Eur J of Phys Rehabil Med. 2010;46(3):347-53.

13. Stevens VK, Coorevits PL, Bouche KG et al. The influence of specific training on trunk muscle recruitment patterns in healthy subjects during stabilization exercises. Man Ther. 2007;12(3):271-9.

14. Standaert CJ, Weinstein SM, Rumpeltes J. Evidence-informed management of chronic low back pain with lumbar stabilization exercises. The spine journal. 2008;8(1):114-20.

15. Richardson CA, Hides JA, Wilson S et al. Lumbo-pelvic joint protection against antigravity forces: motor control and segmental stiffness assessed with magnetic resonance imaging. J Gravit Physiol. 2004;11(2):119-22.

16. Akuthota V, Nadler SF. Core strengthening. Arch Phys Med Rehabil. 2004;85(3 Suppl 1):S86-92.

17. Kisner C, Colby LA, Borstad J. Therapeutic exercise: foundations and techniques. 7th edition, Philadelphia, Fa Davis, 2017.

18. McMeeken JM, Beith ID, Newham DJ et al. The relationship between emg and change in thickness of transversus abdominis. Clin Biomech. 2004;19(4):337-42.

19. Chon SC, Chang KY, You JS. Effect of the abdominal draw-in manoeuvre in combination with ankle dorsiflexion in strengthening the transverse abdominal muscle in healthy young adults: A preliminary, randomised, controlled study. Physiotherapy. 2010;96(2):130-6.

20. Kim YY, Kim TH, Noh JS et al. The influence of abdominal drawing-in maneuver on lumbar lordosis and trunk and lower extremity muscle activity during bridging exercise. Kor Res Soc Phys Ther. 2009;16(1):1-9.

21. Mannion AF, Pulkovski N, Gubler D et al. Muscle thickness changes during abdominal hollowing: An assessment of between-day measurement error in controls and patients with chronic low back pain. Eur Spine J. 2008;17(4):494-501.

22. Teyhen DS, Miltenberger CE, Deiters HM et al. The use of ultrasound imaging of the abdominal drawing-in maneuver in subjects with low back pain. J Orthop Sports Phys Ther. 2005;35(6):346-55.

23. Whittaker JL. Ultrasound imaging of the lateral abdominal wall muscles in individuals with lumbopelvic pain and signs of concurrent hypocapnia. Man Ther. 2008;13(5):404-10.

24. Cairns MC, Harrison K, Wright C. Pressure biofeedback: A useful tool in the quantification of abdominal muscular dysfunction? Physiotherapy. 2000;86(3):127-38.

25. Critchley DJ, Pierson Z, Battersby G. Effect of pilates mat exercises and conventional exercise programmes on transversus abdominis and obliquus internus abdominis activity: Pilot randomised trial. Man Ther. 2011;16(2):183-9.

26. Seo DK, Kwon OS, Kim JH et al. The effect of trunk stabilization exercise on the thickness of the deep abdominal muscles and balance in patients with chronic stroke. J Phys Ther Sci. 2012;24(2):181-5.

27. Jun CB. Effects of a trunk stabilization exercise on the thickness of the deep abdominal muscles and balance. Daegu University. Dissertation of Doctorate Degree. 2012.

28. Lee SK, Jung JH. Effects of indoor horse-riding exercise on health related physical fitness factors, blood lipid concentration, and bowel movement satisfaction of female college students. J Kor Sport Res. 2005;16(3):15360.

29. Hides JA, Richardson CA, Jull GA. Multifidus muscle recovery is not automatic after resolution of acute, first-episode low back pain. Spine. 1996;21(23):2763-9.

30. Vera-Garcia FJ, Grenier SG, McGill SM. Abdominal muscle response during curl-ups on both stable and labile surfaces. Phys Ther. 2000; 80(6):564-9.

31. Behm DG, Anderson K, Curnew RS. Muscle force and activation under stable and unstable conditions. J Strength Cond Res. 2002;16(3):416-22. 